PUBLIK: Jurnal Manajemen Sumber Daya Manusia, Adminsitrasi dan Pelayanan Publik Sekolah Tinggi Ilmu Administrasi Bina Taruna Gorontalo Volume VIII Nomor 1, 2021

\title{
PERAN PEMIMPIN DALAM ORGANISASI PELAYANAN SOSIAL UPTD PESANGGRAHAN PMKS MAJAPAHIT KABUPATEN MOJOKERTO
}

\author{
Pristhalia Vernanda Gunawan ${ }^{1}$; Soni Akhmad Nulhaqim² \\ Universitas Padjadjaran \\ Pristhalia123@gmail.com ${ }^{1}$; $\underline{\text { Soni.nulhaqim@ } @ \text { unpad.ac.id }}{ }^{2}$
}

\begin{abstract}
ABSTRAK
Metode yang digunakann dalam penelitian ini adalah metode deskriptif kualitatif yang bertujuan untuk menganalisis peran pemimpin dalam organisasi pelayanan sosial di UPTD Pesanggrahan PMKS Majapahit. UPTD Pesanggrahan PMKS Majapahit merupakan organisasi pelayanan sosial di bawah Dinas Sosial Kabupaten Mojokerto yang dipimpin oleh seorang Kepala UPTD. Kepala UPTD sebagai pemimpin telah berpengalaman dalam bidang sosial, manajemen, dan administrasi sehingga dapat membawa UPTD Pesanggrahan PMKS Majapahit menjadi organisasi pelayanan sosial yang dapat diandalkan. Peran Kepala UPTD sebagai pemimpin merupakan salah satu faktor penting keberhasilan UPTD Pesanggrahan PMKS Majapahit. Oleh sebab itu dilalukan analisis terhadap peran Kepala UPTD Pesanggrahan PMKS Majapahit dalam menjalankan fungsi dan tugasnya. Hasil penelitian terhadap peran pemimpin menunjukkan bahwa peran pemimpin yang dilakukan oleh Kepala UPTD meliputi accepting; caring, creating, democratizing, planning, dan organizing. Peran yang dilakukan oleh Kepala UPTD melalui tindakan tersebut tidak terlepas dari keterlibatan seluruh unsur baik staf dan klien atau penerima manfaat dengan memberikan pendapat dan saran demi peningkatan kualitas UPTD Pesanggrahan PMKS Majapahit. Adapun yang perlu diperhatikan untuk menunjang peran Kepala UPTD dalam menjalankan fungsi dan tugasnya, yaitu disarankan agar Kepala UPTD memperluas pengetahuan dan wawasan tentang organisasi layanan sosial, serta pemahaman mengenai dinamika lingkungan di UPTD Pesanggrahan PMKS Majapahit. Kata Kunci: Peran, Pemimpin, Organisasi Pelayanan Sosial
\end{abstract}

\section{ABSTRACT}

The method used in this study is a qualitative descriptive method which aims to analyze the role of leaders in social service organizations at UPTD Pesanggrahan PMKS Majapahit. UPTD Pesanggrahan PMKS Majapahit is a social service organization under the Social Service of Mojokerto Regency which is led by a Head of UPTD. The head of UPTD as a leader has experience in social, management, and administration fields so that he can bring UPTD Pesanggrahan PMKS Majapahit into a reliable social service organization. The role of the Head of the UPTD as a leader is one of the important factors in the success of the UPTD Pesanggrahan PMKS Majapahit. Therefore, an analysis was carried out on the role of the Head of the UPTD Pesanggrahan PMKS Majapahit in carrying out its functions and duties. The results of the research on the role of the leader indicate that the role of the leader carried out by the Head of UPTD includes accepting; caring, creating, democratizing, planning, and organizing. The role carried out by the Head of UPTD through these actions cannot be separated from the involvement of all elements, both staff and clients or beneficiaries by providing opinions and suggestions for improving the quality of UPTD Pesanggrahan PMKS Majapahit. As for what needs to be considered to support the role of 
PUBLIK: Jurnal Manajemen Sumber Daya Manusia, Adminsitrasi dan Pelayanan Publik Sekolah Tinggi Ilmu Administrasi Bina Taruna Gorontalo Volume VIII Nomor 1, 2021

the Head of the UPTD in carrying out its functions and duties, it is recommended that the Head of the UPTD expand knowledge and insight about social service organizations, as well as an understanding of environmental dynamics in the UPTD Pesanggrahan PMKS Majapahit.

Keywords: Roles, Leaders, Social Service Organizations

\section{PENDAHULUAN}

Organisasi pelayanan sosial merupakan salah satu kunci utama dalam menjawab permasalahan sosial dengan memberikan layanan berbasis organisasi terhadap pemerlu pelayanan atau penyandang masalah kesejahteraan sosial. Layanan sosial yang diberikan disesuaikan dengan kondisi dan kebutuhan klien, seperti layanan sosial dalam bentuk perawatan dan rehabilitasi sosial sebagai upaya mencapai kesejahteraan sosial. Undangundang No. 11 Tahun 2009 tentang kesejahteraan sosial menjelaskan bahwa kesejahteraan sosial merupakan kondisi terpenuhinya kebutuhan materil, spiritual, dan sosial untuk dapat hidup layak dan mampu mengembangkan diri sendiri sehingga dapat melaksanakan fungsi sosialnya. Pengertian tersebut sejalan dengan pendapat Hasenfeld dalam Jones \& May (1992) yang mengungkapkan bahwa organisasi pelayanan sosial merupakan sekumpulan individu-individu yang tergabung dalam suatu organisasi yang memiliki fungsi melindungi, memelihara maupun meningkatkan kesejahteraan individu. Organisasi pelayanan sosial terdiri dari beberapa komponen subjek yang saling berkaitan dan mendukung yang meliputi pemimpin dan staf-staf yang berada dibawahnya. Keberhasilan dari sebuah layanan sosial salah satunya dapat dilihat dari baiknya sistem administrasi dan koordinasi antara pemimpin dengan stafnya. Administrasi dalam hal ini diartikan sebagai proses menjalankan lembaga dengan melibatkan tujuan, kebijakan, staf, manajemen, layanan dan evaluasi. Adapun sebagai komponen utama dalam pemberian pelayanan sosial yang dikontrol secara langsung oleh seorang atasan atau pimpinan dengan cara memfasilitasi kerja organisasi dan staf (Skidmore. et al. ; dikutip oleh Maryatun \& Nulhaqim, 2020).Sebuah tantangan bagi pemimpin untuk membentuk sistem administrasi dan koordinasi yang baik mengingat latar belakang pendidikan dan pengalaman staf yang berbeda-beda, oleh karena itu sangat dibutuhkan pemimpin yang kompeten untuk mengoordinasikan sebuah lembaga atau organisasi pelayanan sosial sehingga pelayanan sosial yang diberikan dapat efektif dan efisien.

Pemimpin dalam hal ini adalah seseorang yang memiliki peran penting sebagai administrator pekerjaan sosial dalam organisasi pelayanan sosial. Administrasi pekerjaan sosial merupakan suatu perubahan kebijakan sosial ke dalam pelayanan sosial melalui proses dua arah yaitu mengubah kebijakan menjadi layanan sosial yang nyata dan menggunakan pengalaman yang ada dalam merekomendasikan transformasi kebijakan 
PUBLIK: Jurnal Manajemen Sumber Daya Manusia, Adminsitrasi dan Pelayanan Publik Sekolah Tinggi Ilmu Administrasi Bina Taruna Gorontalo Volume VIII Nomor 1, 2021

(Skidmore; dikutip oleh Maryatun \& Nulhaqim, 2020). Proses administrasi pekerjaan sosial tentu tidak mudah bagi seorang pemimpin, maka diperlukannya pendidikan, sikap, dan keterampilan dalam bertindak untuk mewujudkan keberhasilan organisasi pelayanan sosial. Pekerjaan sosial sering menjelaskan bahwa pendidikan mereka mencakup pengetahuan, sikap profesional, dan keterampilan (Skidmore; dikutip oleh Maryatun \& Nulhaqim, 2020). Kerangka ini digunakan oleh administrator pekerjaan sosial sebagai pemimpin untuk menjadi lebih baik dan profesional. Pada hakikatnya, tidak ada administrator yang sempurna namun memiliki kemampuan untuk memahami proses dan keterampilan administrasi yang memungkinkan organisasi dan pelayanannya menjadi efektif kepada penerima manfaat. Kerangka yang telah disebutkan meliputi pengetahuan, sikap, dan keterampilan menjadi dasar seorang pekerja sosial yang bekerja dalam sebuah organisasi pelayanan sosial untuk mewujudkan tujuannya, terutama pada aspek pelayanan sosial.

Terdapat beberapa pengetahuan yang penting dimiliki oleh seorang administrator pekerjaan sosial atau dalam hal ini adalah pemimpin organisasi pelayanan sosial seperti mengetahui tujuan organisasi, kebijakan, pelayanan, dan sumber daya; memahami pelayanan yang sedang dan akan dilaksanakan; memahami sejarah atau latar belakang organisasi dan kemungkinan di masa depan; mengetahui dinamika perilaku manusia memahami staf atau bawahannya (Skidmore; dikutip oleh Maryatun \& Nulhaqim, 2020). Pada dasarnya pengetahuan tersebut digunakan olehpemimpin dalam sebuah organisasi pelayanan manusia agar mampu melakukan koordinasi, monitoring, dan evaluasi dengan baik terhadap proses pelaksanaannya. Pemimpin yang kompeten tentunya juga memiliki sekumpulan sikap yang profesional. Beberapa sikap professional yang diadopsi dari administrator pekerjaan sosial yang suksesmeliputi sikap kepedulian; mengakui bahwa tidak ada yang sempurna dam menerima pencapaian staf denga apa adanya; menciptakan situasi lingkungan yang baik; menyadari pentingnya nilai; memiliki sikap penerimaan terhadap ide baru dan realita; dan menyadari bahwa kesejahteraan organisasi lebih penting.

Pemimpin yang memiliki pengetahuan dan sikap profesional, maka selanjutnya akan menjalankan perannya melalui tindakan-tindakan administrasi pekerjaan sosial ntuk mencapai tujuan sebuah organisasi pelayanan sosial. Terdapat 18 tindakan pemimpin yang kompeten meliputi accepting, caring, creating, democratizing, trusting, approving, maintaining personal equilibrium and balance, planning, organzing, setting priorities, delegating, interacting with community and professions, decision making, facilitating, communicating, timing, building, and motivating (Skidmore; dikutip oleh Maryatun \& Nulhaqim, 2020). Tindakan pemimpin merupakan bagian aktualisasi dari pengetahuan dan sikap professional yang telah dimiliki dalam diri. Sinergitas antara kerangka pengetahuan, 
PUBLIK: Jurnal Manajemen Sumber Daya Manusia, Adminsitrasi dan Pelayanan Publik Sekolah Tinggi Ilmu Administrasi Bina Taruna Gorontalo Volume VIII Nomor 1, 2021

sikap professional dan tindakan menjadi kunci utama seorang pemimpin yang sukses menjalankan sebuah organisasi pelayanan sosial. Penelitian Usep (2019), menyebutkan bahwa pemimpin dalam sebuah organisasi memiliki peranan penting dan menjadi salah satu faktor penentu keberhasilan dalam suatu organisasi. Daswati (2012), juga menyebutkan bahwa pemimpin pada sebuah organisasi sedapat mungkin menjadi agen perubahan, juru bicara dan pelatih. Adapun motivasi seorang pemimpin yang memiliki kendali besar dalam sebuah organisasi menjadi sangat penting dikarenakan pemimpin memiliki pengaruh besar dalam menunjang kinerja staf atau bawahannya (Fazrien, dkk., 2014). Dengan demikian, analisis terhadap peran pemimpin dalam organisasi pelayanan sosial sangat diperlukan, mengingat peranannya sangat berpengaruh terhadap keberhasilan dan pencapaian tujuan.

UPTD Pesanggrahan PMKS Majapahit merupakan lembaga atau organisasi yang bergerak dalam pelayanan sosial dan berada di bawah naungan Dinas Sosial Kabupaten Mojokerto. UPTD ini memberikan pelayanan sosial terhadap penyandang masalah kesejahteraan sosial (PMKS) sejak tahun 2018 yang sebelumnya hanya memberikan pelayanan terhadap lanjut usia terlantar saja. PMKS yang menjadi penerima manfaat dalam hal ini adalah yang terdaftar dalam Peraturan Menteri Sosial No. 08 Tahun 2012 tentang Pedoman Pendataan dan Pengelolaan Data Penyandang Masalah Kesejahteraan Sosial dan Potensi dan Sumber Kesejahteraan Sosial. Berdasarkan Peraturan Bupati Mojokerto No. 25 Tahun 2018, UPTD Pesanggrahan PMKS Majapahit memberikan pelayanan sosial dalam bentuk rehabilitasi, perawatan, bimbingan, dan advokasi terhadap penyandang masalah kesejahteraan sosial (PMKS).

Sebagai organisasi pelayanan sosial di Kabupaten Mojokerto, UPTD ini pun cukup berhasil menangani PMKS yang ada dengan melakukan pelayanan sosial seperti perawatan dan rehabilitasi sosial. Keberhasilan tersebut terbukti dari mayoritas penjangkauan (outreach) yang dilakukan oleh Dinas Sosial atau lembaga lain dan laporan pihak lain yang menemukan PMKS langsung diarahkan ke UPTD Pesanggrahan PMKS Majapahit sebagai lembaga yang memberikan pelayanan sosial terpercaya. Selain itu, UPTD Pesanggrahan Majapahit mengarahkan PMKS yang telah selesai mendapatkan pelayanan sosial akan menyalurkan PMKS tersebut kembali ke keluarganya atau diserahkan ke lembaga pelatihan dan pemberdayaan bagi PMKS yang berorientasi untuk meningkatkan keberfungsian sosial ekonominya. Hal tersebut tentunya tidak terlapas dari peran pemimpin yaitu Kepala UPTD yang berhasil dalam mengupayakan sistem administrasi pekerjaan sosial dan koordinasi yang baik dengan staf-stafnya. Peran yang ditunjukkan oleh Kepala UPTD tersebut dioperasionalkan dalam beberapa bentu tindakan. Berdasarkan tindakan yang telah 
PUBLIK: Jurnal Manajemen Sumber Daya Manusia, Adminsitrasi dan Pelayanan Publik Sekolah Tinggi Ilmu Administrasi Bina Taruna Gorontalo Volume VIII Nomor 1, 2021

diuraikan menyebutkan bahwa tindakan administrator pekerjaan sosial yang kompeten atau dalam hal ini adalah Kepala UPTD Pesanggrahan PMKS Majapahit maka aspek tindakan yang akan dianalisis meliputi tindakan accepting, caring, creating, democratizing, planning, dan organizing. Beberapa aspek tindakan tersebut ditentukan berdasarkan kesesuaian tugas pokok dan fungsi Kepala UPTD Pesanggarah PMKS Majapahit, proses koordinasi dengan para staf, dan pelaksanaan pelayanan sosial kepada penerima manfaat.

Berdasakan latar belakang yang telah dijelaskan, maka fokus permasalahan dalam penelitian ini adalah bagaimana peran Kepala UPTD di UPTD Pesanggrahan PMKS Majapahit Kabupaten Mojokerto yang ditinjau dari beberapa aspek meliputi accepting, caring, creating, democratizing, planning, dan organizing. Tujuan dari penelitian ini adalah untuk mengetahui lebih dalam mengenai peran pemimpin dalam hal ini adalah Kepala UPTD di UPTD Pesanggrahan PMKS Majapahit Kabupaten Mojokerto.

\section{METODE PENELITIAN}

Metode penelitian yang digunakan dalam penelitian ini adalah metode deskriptif dengan pendekatan kualitatif. Menurut Sukmadinata (2011), penelitian deskriptif kualitatif bertujuan untuk memberikan deskripsi dan gambaran tentang fenomena yang terjadi, dengan memperhatikan karakteristik, kualitas, dan keterkaitan antar kejadian. Metode deskriptif kualitatif dalam penelitian ini bertujuan untuk menganalisis peran pemimpin dalm organisasi pelayanan sosial di UPTD Pesanggrahan PMKS Majapahit. Penelitian ini dilakukan dengan menggunakan wawancara, observasi, dan studi dokumentasi terhadap profil organisasi, tinjauan konseptual, dan penelitian terdahulu. Informan dalam penelitian adalah Kepala UPTD Pesanggarahan PMKS Majahit dan beberapa staf, hal ini dimaksudkan untuk mendapatkan data secara komprehensif.

\section{HASIL PEMBAHASAN}

Pesanggrahan PMKS Majapahit sebagai organisasi di bawah naungan Dinas Sosial melaksanakan kegiatan teknis operasional atau penunjang tertentu di bidang sosial yaitu melaksanakan pelayanan dan rehabilitasi bagi PMKS. Organisasi ini dipimpin oleh Kepala UPTD yang memiliki tugas memimpin, merencanakan, mengoordinasi, melaksanakan, mengendalikan, mengawasi, dan mengevaluasi seluruh kegiatan UPTD. Pelaksanaan tugas tersebut dibantu oleh tenaga atau staf yang berjumlah 24 Non-ASN dengan rincian tugas melakukan perawatan medis, perawatanklien, keamanan, pemenuhan kebutuhan fisik, dan kebersihan serta pelaksana tugas tambahan yaitu seorang psikolog dan penceramah agama.

Tata kerja Kepala UPTD Pesanggrahan PMKS Majapahit (Peraturan Bupati Mojokerto No. 25 Tahun 2018), meliputi: 
PUBLIK: Jurnal Manajemen Sumber Daya Manusia, Adminsitrasi dan Pelayanan Publik Sekolah Tinggi Ilmu Administrasi Bina Taruna Gorontalo Volume VIII Nomor 1, 2021

1. Kepala UPTD wajib menerapkan psinsip koordinasi, integrasi, sinkronisasi, dan simplifikasi.

2. Kepala UPTD bertanggung jawabmemimpin dan mengoordinasi staf dan memberikan bimbingan serta petunjuk bagi pelaksanaan tugas.

3. Kepala UPTD bertanggung jawab terhadap pelaksanaan tugas dan melaksanakan pengawasan terhadap staf secara berjenjang.

Keberhasilan sebuah organisasi pelayanan sosial tidak terlepas dari peran seorang pemimpin dalam melakukan administrasi dan koordinasi dengan para stafnya. Kepala UPTD Pesanggrahan PMKS Majapahit merupakan pemimpin sebuah organisasi pelayanan sosial di bawah Dinas Sosial Kabupaten Mojokerto dan hingga saat ini telah melakukan tugas pokok dan fungsinya dengan baik. Peran yang dijalankan oleh pemimpin yang kompeten dapat diuraikan memalui tindakan-tindakan. Berikut analisis tindakan-tindakan dari Kepala UPTD Pesanggrahan PMKS Majapahit dalam melaksanakan tugasnya.

\section{Accepting}

Tindakan accepting atau penerimanaan seorang pemimpin terhadap seluruh staf dan komponen yang ada di organisasi pelayanan sosial menjadi dasar terciptanya keharmonisan. Kepala UPTD telah berpengalaman bekerja pada organisasi pelayanan sosial, sehingga memiliki kemampuan untuk memahami dan menerima perbedaanperbedaan yang ada. Pemimpin mendukung perbedaan staf atau klien sebagai keunikan, serta mendukung setiap staf menjadi diri sendiri pada kerangka kerja, kebijakan, dan prosedur. Tindakan penerimaan ini dilakukan oleh Kepala UPTD dengan memperlakukan staf tanpa membedakan status sosial dan latar belakang pendidikan sehingga terciptanya lingkungan dan suasana kerja yang hangat, bersahabat dan penuh keakraban. Perbedaan yang ada tentunya telah disesuaikan dengan bidang pekerjaan yang dihadapi oleh setiap staf dan keahlian dalam memberikan pelayanan kepada klien, seperti staf dengan latar belakang pendidikan psikologi akan bekerja pada bidang pelayanan konseling. Keserasian sistem pelayanan yang ditangani oleh berbagai keahlian staf ini erat kaitannya dengan kemampuan Kepala UPTD dalam menentukan tujuan, standar, dan pedoman kerja bagi setiap staf sesuai dengan bidangnya. Hal tersebut selaras dengan tata kerja Kepala UPTD dalam Peraturan Bupati Mojokerto No. 25 Tahun 2018.

Tindakan penerimaan diterapkan oleh Kepala UPTD pada saat melaksanakan rapat rutin setiap bulan bersama staf dan apabila terjadi permasalahan yang bersifat urgent untuk segera ditangani. Pada saat rapat, Kepala UPTD menerima dengan sangat terbuka bagi stafstaf yang menyampaikan saran dan pendapatnya pada sesi diskusi. Dalam proses pengambilan keputusan, Kepala UPTD mengikutsertakan staf-stafnya untuk menetapkan 
PUBLIK: Jurnal Manajemen Sumber Daya Manusia, Adminsitrasi dan Pelayanan Publik Sekolah Tinggi Ilmu Administrasi Bina Taruna Gorontalo Volume VIII Nomor 1, 2021

prioritas dengan cara menerima masukan yang selanjutnya akan didiskusikan bersama melalui penetapan skala prioritas sehingga menghasilkan keputusan akhir yang tepat. Pada saat kegiatan sehari-hari, penerimaan juga ditunjukkan oleh Kepala UPTD kepada seluruh staf bahkan klien atau penerima manfaat di lingkungan UPTD Pesanggrahan PMKS Majapahit. Tindakan-tindakan tersebut meliputi mengobrol atau diskusi ringan dengan staf, sharing masalah pekerjaan dan perkembangan klien yang sedang ditangani, membangun peer group khusus untuk meringankan kesulitan pekerjaan dengan mendengarkan pengalaman menyelesaikan kesulitan atau coping strategy setiap staf selama menjalani dinamika di UPTD Pesanggrahan PMKS Majapahit.

\section{Caring}

Caring atau kepedulian yang dimiliki oleh seorang pemimpin terhadap seluruh staf atau bawahannya menjadi hal yang menarik sebagai upaya mewujudkan suasana lingkungan kerja yang kohesif. Kohesivitas merupakan kelekatan individu terhadap kelompok atau organisasi dan motivasi mereka untuk bersatu dimana hal tersebut menjadi penting dalam keberhasilan suatu organisasi (Mcshane \& Glinow, 2010). Berdasarkan pendapat tersebut dapat disimpulkan bahwa kohesivitas seluruh komponen organisasi sangat penting diupayakan karena menjadi salah satu faktor pendukung keberhasilan sebuah organisasi pelayanan sosial. Adapun tindakan pemimpin yang peduli salah satunya adalah pemimpin memberikan aura kehangatan danrasa memiliki. Tindakan kepedulian ini menjadi ciri khas seorang Kepala UPTD dalam menjalankan tugasnya di UPTD Pesanggrahan PMKS Majapahit. Hal tersebut terlihat jelas dengan melihat suasana yang dibangun di lokasi tersebut sangatlah tenang dan seluruh unsur yang ada baim staf maupun klien atau penerima manfaat saling berinteraksi baik secara verbal maupun non verbal dengan hangat. Tindakan kepedulian dilakukan oleh Kepala UPTD dengan menanamkan rasa memiliki (sense of belonging) akan keberadaan UPTD Pesanggarahan PMKS Majapahit dan seluruh unsur yang ada di dalamnya sehingga pelaksanaan tugas-tugas didasari rasa tanggung jawab dan kepedulian dari dalam hati, bukan karena keterpaksanaan maupun tekanan.

Kepala UPTD memiliki tiga kunci sukses dalam melaksanakan kepedulian terhadap para stafnya, yaitu senyum, sapa, salim (dalam Bahasa Indonesia artinya berjabat tangan). Ketiga kunci sukses tersebut dilakukan oleh Kepala UPTD dalam keseharian melaksanakan tugasnya. Senyum dan sapa adalah bagian awal dalam membangun komunikasi dan meruntuhkan gap antara Kepala UPTD dan para stafnya, selanjutnya salim dilakukan untuk membangun suatu kepercayaan para staf bahwa Kepala UPTD serius dalam menjalin hubungan yang baik dengan mereka. Kunci sukses yang telah dilakukan oleh Kepaa UPTD 
PUBLIK: Jurnal Manajemen Sumber Daya Manusia, Adminsitrasi dan Pelayanan Publik Sekolah Tinggi Ilmu Administrasi Bina Taruna Gorontalo Volume VIII Nomor 1, 2021

memberikan dampak yang besar pada tindakan kepedulian terhadap seluruh staf. Adapun tindakan konkrit yang menjadi kebiasaan Kepala UPTD adalah seling dan juling yaitu aktivitas senin dan jum'at keliling dimana setiap pada hari itu Kepala UPTD akan berkeliling ke setiap tempat untuk bertemu seluruh staf dan klien atau penerima manfaat dengan mengobrol ringan dan mendengarkan cerita tentang kesan berada di UPTD Pesanggrahan PMKS Majapahit.

\section{Creating}

Kreativitas pemimpin memang sangat diperlukan dalam menciptakan suatu kebaharuan pada organisasi, terutama organisasi pelayanan sosial yang langsung berhubungan dengan manusia. Pemimpin dituntut untuk kreatif dalam merintis atau menetapkan kebijakan, metode, dan prosedur inovatif sehingga dapat meningkatkan layanan dan hubungan staf, fleksibel, serta berusaha meningkatkan pengetahuan tentang metode dan prosedur yang baru dan efektif. Kebijakan, metode, dan prosedur yang inovatif akan memberikan dampak pada suatu layanan yang terbaik dengan staf sebagai pelaksananya. Hal tersebut juga sangat berpengaruh terhadap staf dalam menjalani pekerjaan dan aktivitas koordinasi baik ke atasan maupun antar staf lainnya. Kepala UPTD telah menciptakan suatu kebaharuan dengan menciptakan prosedur dalam menjalankan evaluasi melalui "Kotak Sumbang Saran" yang merupakan sebuah kotak yang diletakkan di setiap bagian ruangan kerja dimana staf bisa memberikan saran, pendapat, maupun kritikan terhadap sistem koordinasi, pelayanan, ketetapan kebijakan, dan lain sebagainya. Selain itu,

Kepala UPTD juga menetapkan metode pelayanan yang cukup unik bagi beberapa PMKS seperti anak terlantar dan lanjut usia terlantar.Metode unik tersebut adalah dengan membentuk sebuah kelompok kecil bagi PMKS sesuai jenisnya dimana kelompok tersebut dibentuk pada saat pemberian layanan seperti konseling dan biasanya juga diarahkan untuk saling berbagi cerita serta diharapkan dapat membantu menurunkan rasa kesepian. Adapun Kepala UPTD menciptakan inovasi dalam program atau kegiatan yang ada di di UPTD Pesanggarahan PMKS Majapahit, seperti program andalan "Halo Dokter" dalam kegiatan pemeriksaan kesehatan dan posyandu khusus lanjut usia. Program "Halo Dokter" diciptakan untuk memfasilitasi kebutuhan pelayanan kesehatan bagi seluruh klien atau penerima manfaat dengan melibatkan seluruh unsur tidak hanya tenaga kesehatan saja melainkan tenaga keamanan, kebersihan, dan lain sebagainya sehingga pelaksanaan program atau kegiatan ini bisa berjalan dengan baik dan tepat sasaran.

\section{Democratizing}

Demokratisasi dapat diartikan sebagai tindakan yang dilakukan oleh pemimpin dengan melibatkan beberapa pihak di dalamnya dan secara terbuka menerima saran serta 
PUBLIK: Jurnal Manajemen Sumber Daya Manusia, Adminsitrasi dan Pelayanan Publik Sekolah Tinggi Ilmu Administrasi Bina Taruna Gorontalo Volume VIII Nomor 1, 2021

masukan untuk menentuka keputusan yang tepat dan terbaik. Kepala UPTD mengedepankan musyawarah dalam pengambilan keputusan atau kebijakan di UPTD Pesanggarahan PMKS Majapahit, seperti pengadaan "Kotak Sumbang Saran” untuk bahan pertimbangan evaluasi dan sesi diskusi untuk menampung masukan seluruh staf pada saat rapat koordinasi atau rutin sehingga demokratisasi terwujud. Selain itu, aktivitas Kepala UPTD dalam melaksanakan tugas sehari-hari juga tidak terlepas dengan proses demokratisasi melalui obrolan-obrolan ringan untuk pengambilan keputusan kecil. Adapun poin penting dalam penerapan demokratisasi yaitu demokrasi tidak hanya berlaku pada saat kepentingan pengambilan keputusan besar seperti dalam rapat, namun pada aktivitas seharihari juga perlu diterapkan.

Kepala UPTD menjelaskan bahwa rapat dengan staf merupakan media yang tepat untuk menampung segala aspirasi seperti saran, pendapat maupun keluhan staf terkait pelaksanaan tugas. Selanjutnya, untuk pengambilan keputusan yang menyangkut kebijakan atau prosedur organisasi didasarkan pada hasil rapat dengan staf. Demokratisasi yang diterapkan oleh Kepala UPTD juga sejalan dengan tata kerja Kepala UPTD yang wajib menerapkan psinsip koordinasi, integrasi, sinkronisasi, dan simplikasi. Kepala UPTD juga memiliki pandangan bahwa setiap individu diberikan kebebasan untuk menyampaikan tanpa ada rasa rendah diri dikarenakan semua orang memiliki kedudukan yang sama, yang membedakan adalah tugas dan tanggung jawabnya. Dengan demikian, melalui prinsip dan pandangan Kepala UPTD dapat memberikan dampak yang begitu besar terhadap peningkatan kualias UPTD Pesanggrahan PMKS Majapahit sebagai organisasi pelayanan sosial yang bernuansa demokrasi.

\section{Planning}

Perencanaan dalam sebuah organisasi pelayanan sosial dilakukan oleh seorang pemimpin dengan segala unsur di dalamnya dengan memeprtimbangan kebijakan dan aturan yang ada.Kepala UPTD sebagai pemimpin di sebuah organisasi pelayanan sosial UPTD Pesanggrahan PMKS Majapahit merupakan pemeran utama dalam perencanaan baik kebijakan, prosedur, maupun program yang ada. Setiap program atau kegiatan rutin yang ada di UPTD Pesanggarahan PMKS Majapahit juga telah dituangkan dalam prosedur dan aturan baku, sehingga pelaksanaan kegiatan lebih terarah dan tidak melenceng dari sasaran. Adapun perencanaan tentang anggaran program atau kegiatan ditetapkan dalam Rencana Kerja Anggaran (RKA).

Salah satu program yang telah berjalan sesuai rencana adalah program rehabilitasi bagi orang terlantar dengan menerapkan SOP (standar operating prosedur) yang ada. Bagi orang terlantar di wilayah desa atau kelurahan, proses diawali dengan surat usulan dari 
PUBLIK: Jurnal Manajemen Sumber Daya Manusia, Adminsitrasi dan Pelayanan Publik Sekolah Tinggi Ilmu Administrasi Bina Taruna Gorontalo Volume VIII Nomor 1, 2021

pemerintah desa atau kelurahan ditujukan kepada Kepala Dinas Sosial Kabupaten Mojokerto, mengetahui camat setempat dengan tembusan Kepala UPTD Pesanggrahan PMKS Majapahit. Selanjutnya, usulan ditindaklanjuti dengan survei terhadap sasaran (orang terlantar), jika memenuhi persayaratan maka orang terlantar dapat segera ditempatkan dan mendapat rehabilitasi di UPTD Pesanggrahan PMKS Majapahit. Selanjutnya, bagi orang terlantar yang terjaring razia pekat langsung ditempatkan di UPTD Pesanggarahan PMKS Majapahit, selanjutnya Kepala UPTD akan berkoordinasi dengan Dinas Kependudukan dan Catatan Sipil untuk mencari data tentang asal-usul orang terlantar tersebut. Jika berhasil, maka warga terlantar tersebut akan dikembalikan ke daerah asal atau diserahkan ke Dinas Sosial setempat, namun jika tidak maka orang terlantar tersebut akan menjadi penerima manfaat di UPTD Pesanggrahan PMKS Majapahit.

\section{Organizing}

Organisasi yang efektif mengikuti perencanaan yang baik, jika tidak maka organisasi tidak akan efektif. Kepala UPTD Pesanggrahan PMKS Majapahit memiliki kemampuan mengorganisasikan lembaga pelayanan sosial baik secara internal maupun ekternal. Dalam urusan internal, Kepala UPTD memiliki prinsip integritas dan sistem koordinasi untuk menjalankan tugas dan fungsinya, serta mengarahkan seluruh staf sesuai bidang pekerjaan mereka masing-masing, sedangkan untuk urusan eksternal Kepala UPTD menerapkan prinsip kerja sama dengan lembaga atau instansi lain dalam mendukung pelayanan sosial yang ada. Sebagai organisasi pelayanan sosial yang memiliki sasaran yang luas, UPTD Pesanggrahan PMKS Majapahit menjalin kerja sama dengan banyak instansi, khususnya dalam penanganan lanjut usia dan orang terlantar, seperti koordinasi dengan Dinas Sosial, Dinas Kependudukan dan Catatan Sipil, Pemerintah Desa, Puskesmas, dan Muspika (Musyawarah Pimpinan Kecamatan).

Pengorganisasian internal UPTD Pesanggrahan PMKS Majapahit yang dilakukan oleh Kepala UPTD mencakup penetapan sistem koordinasi kerja dengan alur ke segala arah (atas-bawah-samping); sinkronisasi dan simplifikasi unit kerja staf sesuai dengan latar belakang, keahlian, dan pengalaman; prosedur pelayanan dan rehabilitasi untuk penerima manfaat; penetapan standar pelayanan dan rehabilitasi; serta monitoring dan evaluasi berkala secara komprehensif dengan melibatkan seluruh staf melalui laporan pertanggung jawaban. Keterlibatan seluruh staf dalam proses pengorganisasian menjadi sangat penting, mengingat masukan dan kritik akan meningkatkan kualitas pelayanan yang telah dirancang di UPTD Pesanggrahan PMKS Majapahit menjadi lebih baik dan modern. 
PUBLIK: Jurnal Manajemen Sumber Daya Manusia, Adminsitrasi dan Pelayanan Publik Sekolah Tinggi Ilmu Administrasi Bina Taruna Gorontalo Volume VIII Nomor 1, 2021

\section{KESIMPULAN}

Berdasarkan uraian tentang peran pemimpin dalam organisasi pelayanan manusia di UPTD Pesanggrahan PMKS Majapahit yang dipegang oleh Kepala UPTD, maka dapat disimpulkan bahwa peran Kepala UPTD sebagai pemimpin yang cukup berhasil dalam organisasi pelayanan sosial di UPTD Pesanggrahan PMKS Majapahit meliputi accepting, caring, creating, democratizing, planning, dan organizing. Seluruh peran yang dilakukan melalui tindakan tersebut tidak terlepas dari keterlibatan seluruh unsur baik staf dan klien atau penerima manfaat dimana selalu ada masukan dan kritik demi tercapainya tujuan dan meningkatkan kualitas UPTD Pesanggrahan PMKS Majapahit. Prinsip-prinsip yang dimiliki oleh Kepala UPTD sebagai faktor pendukung utama dalam melaksanakan fungsi dan tugasnya, serta membangun sistem koordinasi yang baik dengan seluruh unsur yang ada di UPTD Pesanggrahan PMKS Majapahit. Saran terkait dengan peran Kepala UPTD sebagai pemimpin dalam organisasi pelayanan sosial di UPTD Pesanggrahan PMKS Majapahit selain tetap mempertahankan dan meningkatkan perannya, Kepala UPTD perlu memperluas pengetahuan dan wawasan tentang organisasi layanan sosial untuk meningkatkan kapasitas diri dalam meningkatkan kualitas pelayanan sosial dan sistem administrasi yang baik. Kepala UPTD sebagai pemeran utama juga perlu memahami dinamika yang ada di lingkungan organisasi baik staf maupun klien atau penerima manfaat sebagai upaya terciptanya suasana yang kondusif.

\section{DAFTAR PUSTAKA}

Daswati. (2012). Implementasi Peran Kepemimpinan Dengan Gaya Kepemimpinan Menuju Kesuksesan Organisasi. Jurnal Academica Fakultas Ilmu Sosial Dan Ilmu Politik, 04(01).

Fazrien, A. (2014). Peran Pemimpin Dalam Pencapaian Kinerja Pegawai: Studi Pada Badan Kepegawaian Daerah Kota Malang. Jurnal Administrasi Publik (JAP), 2(4), 603-607.

Jones, A., \& May, J. (1992). Working in Human Service Organization: A Critical Introduction. Melbourne: Longmand Cheshire.

Maryatun \& Nulhaqim, Soni. (2020). Peran Pimpinan Panti Pelayanan Sosial Pengemis Gelandangan Orang Terlantar (PGOT) Mardi Utomo Dalam Upaya Rehabilitasi Dan Pemberdayaan Untuk KemandirianPemerlu Pelayanan Kesejahteraan Sosial (PPKS). Share Social Work Journal, 10(2), 143-149.

Mcshane, S. L., Glinow, M. A. Von, \&Sharma, R. R. (2010). Organizational Behavior: Emerging Knowledege and Practice for The Real World Fifth Edition. New York: The McGraw-Hill Companies, Inc.

Peraturan Bupati Mojokerto No. 25 Tahun 2018 tentang Pembentukan Unit Pelaksana Teknis Daerah (UPTD) Pada Dinas Sosial Kabupaten Mojokerto.

Peraturan Menteri Sosial No. 08 Tahun 2012 tentang Pedoman Pendataan dan Pengelolaan 
PUBLIK: Jurnal Manajemen Sumber Daya Manusia, Adminsitrasi dan Pelayanan Publik Sekolah Tinggi Ilmu Administrasi Bina Taruna Gorontalo Volume VIII Nomor 1, 2021

Pedoman Pendataan dan Pengelolaan Data PMKS dan PSKS

Suherman, U. D. (2019). Pentingnya Kepemimpinan Dalam Sebuah Organisasi. Jurnal Ilmu Akuntansi Dan Bisnis Syariah, 1(2), 259-274.

Sukmadinata, N. S. (2011). Metode Penelitian Pendidikan. Bandung: PT Remaja Rosdakarya.

Undang-Undang No. 11 Tahun 2009 tentang Kesejahteraan Sosial. 